\title{
Hubungan Jumlah Rakaat Salat Dhuha terhadap Peningkatan Detak Jantung
}

\section{Correlation of the Number Rakaat Salat Dhuha for Increased Heart Rate}

\author{
Moch. Arief Prasetya ${ }^{1}$, Muhammad Hasan ${ }^{2}$, Kristianningrum Dian Sofiana ${ }^{3^{*}}$ \\ ${ }^{1}$ Program Studi Pendidikan Dokter, Fakultas Kedokteran Universitas Jember, Jawa Timur, Indonesia \\ ${ }^{2}$ Laboratorium Anatomi, Fakultas Kedokteran Universitas Jember, Jawa Timur, Indonesia \\ ${ }^{3}$ Laboratorium Fisiologi, Fakultas Kedokteran Universitas Jember, Jawa Timur, Indonesia \\ *Corresponding author \\ Email: kdsofiana.fk@unej.ac.id
}

\begin{tabular}{|c|c|}
\hline & $A b s t r a c t$ \\
\hline $\begin{array}{l}\text { Keyword: } \\
\text { Heart rate, } \\
\text { Salat dhuha }\end{array}$ & $\begin{array}{l}\text { Background: Salat is a muslim worship performed with the movement and reading. Salat } \\
\text { types of physical activity with light intensity that can affect heart rate. Heart rate increases } \\
\text { in physical activity according to the increase in intensity. Objectif: This study aims to } \\
\text { determine correlation of the number rakaat salat dhuha for increased heart rate. } \\
\text { Methods:This type of research is analytic observational with a quasi experimental design. } \\
\text { The total sample of } 42 \text { is divided into } 6 \text { treatments, each treatment contains } 7 \text { respondents. } \\
\text { The sampling technique used a simple random sampling method. The research was } \\
\text { conducted from November } 2020 \text { to April } 2021 \text { using respondents' observations. Data } \\
\text { analysis used One Way Anova test and Pearson test. Results: One Way Anova test, which } \\
\text { is a significance value of } 0.001 \text { indicating that there is a difference in the increase in heart } \\
\text { rate prayer intensity and the results of the Pearson test analysis, namely the value of r or } \\
\text { the correlation coefficient of } 0.637 \text { and a significant value of=0.00 shows a strong } \\
\text { relationship between prayer intensity and an increase in heart rate. Conslusion: This study } \\
\text { is that the addition of rakaat salat dhuha increases the heart rate. }\end{array}$ \\
\hline
\end{tabular}

Kata kunci : Detak jantung, Salat dhuha

\begin{abstract}
A B S T R A K
Latar Belakang : Salat merupakan ibadah umat muslim yang dilakukan dengan gerakan dan bacaan. Salat jenis aktivitas fisik dengan intensitas ringan yang dapat memengaruhi detak jantung. Peningkatan detak jantung pada aktivitas fisik sesuai dengan peningkatan intensitasnya. Tujuan: mengetahui hubungan jumlah rakaat salat dhuha terhadap peningkatan detak jantung. Metode: Jenis penelitian ini yaitu analitik observasional dengan rancangan quasi eksperimental. Sampel berjumlah 42 terbagi menjadi 6 perlakuan, tiap perlakuan berisi 7 responden. Teknik pengambilan sampel menggunakan metode simple random sampling. Penelitian dilakukan bulan November 2020 hingga April 2021 menggunakan observasi responden. Analisis data menggunakan uji One Way Anova dan uji Pearson. Hasil: analisis uji One Way Anova yaitu didapatkan nilai signifikansi=0,001 menunjukkan terdapat perbedaan peningkatan detak jantung disetiap intensitas salat serta hasil uji Pearson yaitu nilai $\mathrm{r}$ atau koefisien korelasi sebesar 0,637 dan nilai signifikan $=0,00$ menunjukkan hubungan kuat antara intensitas salat dengan peningkatan detak jantung. Kesimpulan: penambahan rakaat salat dhuha meningkatkan detak jantung.
\end{abstract}

How To Cite: Prasetya, M.A., Hasan, M., \& Sofiana, K.D. 2021. Hubungan Jumlah Rakaat Salat Dhuha terhadap Peningkatan Detak Jantung. Journal of Islamic Medicine. 5(2),106-113.

https://doi.org/10.18860/jim.v5i2.12326

Copyright $@ 2021$ 


\section{LATAR BELAKANG}

Aktivitas fisik merupakan gerakan tubuh yang dihasilkan otot rangka sehingga terjadi pengeluaran energi melebihi istirahat seperti berjalan, bersepeda, menari, bermain, berkebun, melakukan pekerjaan rumah, dan olahraga. Latihan fisik merupakan aktivitas yang dilakukan dengan terencana, terstruktur, dan berkesinambungan dalam upaya meningkatkan kebugaran jasmani. Upaya tersebut dilakukan dengan latihan fisik yang baik, benar, terukur, dan teratur. ${ }^{1}$ Menurut Nurman dkk. serta Pescatello dkk. menyebutkan bahwa aktivitas fisik dapat mencegah hipertensi serta kejadian hipertensi lebih tinggi pada orang dewasa yang tidak aktif dari pada yang aktif. ${ }^{2}$

Upaya pemerintah Indonesia dalam promosi kesehatan seperti melakukan aktivitas fisik setidaknya 30 menit sehari. ${ }^{3}$ Menurut World Health Organization atau WHO, aktivitas fisik yang meningkatkan kesehatan setidaknya dengan intensitas sedang pada kondisi normal. Hal tersebut memungkinkan terjadi peningkatan detak jantung, suhu tubuh, dan ekskresi napas serta nilai metabolisme 3-6 kali dari istirahat (3-6 MET). ${ }^{4}$ Latihan fisik intensitas ringan efektif dalam meningkatkan fisik dan kesehatan kognitif serta bermanfaat dalam promosi kesehatan yang baik, memiliki resiko cedera lebih rendah, dan dapat dilakukan jangka panjang untuk orang berusia lanjut atau dewasa tua. $^{5}$

Pada aktivitas fisik sistem kardiovaskular mampu beradaptasi terhadap aktivitas bersifat akut maupun jangka panjang. Adaptasi akut menunjukkan kapasitas cadangan sistem kardiovaskular yang nantinya bertujuan untuk memenuhi kebutuhan oksigen dan metabolik yang berkelanjutan. ${ }^{6}$ Salah satu bentuk adaptasi terhadap frekuensi denyut jantung pada aktivitas fisik dipengaruhi oleh tidak seimbangnya stimulasi simpatis jantung dan penghambatan saraf vagus. Hal tersebut terjadi akibat pemblokiran saraf otonom ke jantung sehingga terjadi peningkatan ratarata denyut nadi istirahat 70 kali per menit menjadi 100 kali per menit. ${ }^{7}$ Salah satu bentuk manfaat dari aktivitas fisik atau latihan olahraga pada jantung akan mempengaruhi reversibelitas dari respon hipertrofik dan remodeling sehingga menurunkan terjadinya hipertrofik penyakit jantung seperti akibat stres hemodinamik atau hipertensi. ${ }^{6}$

Salat merupakan salah satu bentuk aktivitas fisik intensitas ringan dan mampu meningkatkan koordinasi, sirkulasi, dan kapasitas aerobik. ${ }^{8}$ Gerakan salat diawali takbir dan diakhiri salam. ${ }^{9}$ Penelitian posisi salat terhadap heart rate (HR) didapatkan hasil tertinggi pada posisi berdiri dan terendah pada posisi sujud. ${ }^{10}$ Salat lima waktu merupakan metode yang baik sebagai aktivitas fisik intensitas rendah untuk menjaga fungsi rehabilitasi. ${ }^{11}$ Penelitian Yuksek menunjukkan laki-laki usia lanjut yang melakukan salat memiliki tingkat kebugaran lebih tinggi. ${ }^{12}$

Penelitian-penelitian terdahulu sudah membuktikan efek salat wajib. Namum belum ada yang meneliti efek salat sunah. Salat terbagi menjadi wajib seperti salat subuh, zuhur, dan sebagainya serta sunah seperti dhuha, tahajud, rawatib, dan sebagainya. ${ }^{9}$ Berdasarkan hal tersebut, penelitian ini bertujuan untuk mengetahui hubungan jumlah rakaat salat dhuha terhadap peningkatan detak jantung.

\section{METODE}

Jenis penelitian ini menggunakan metode analitik observasional rancangan quasi eksperimental dengan one group pretest-posttest design. Penelitian ini dilaksanakan di Kabupaten Jember dan di rumah responden menggunakan media teleconference (Zoom) pada bulan November 2020 hingga April 2021. Penelitian ini sudah mendapat persetujuan dari Komisi Etik Fakultas Kedokteran Universitas Jember dengan nomor 1.488/H25.1.11/KE/2021.

Populasi penelitian ini yaitu mahasiswa Fakultas Kedokteran Universitas Jember Angkatan 2017, 2018, dan 2019. Besar sampel dihitung menggunakan rumus 
korelasi sampel tunggal. ${ }^{13}$ Untuk mengantisipasi subjek terpilih yang dropout dengan koefisien $\mathrm{f}=10 \%$. $^{14}$

a. Perhitungan rumus korelasi sampel tunggal

$$
\begin{gathered}
n=\left\{\frac{Z a+Z \beta}{0,5 \operatorname{In}[(1+r) \div(1-r)]}\right\}^{2}+3 \\
n=\left\{\frac{1,96+1,28}{0,5 \operatorname{In}[(1+0,5) \div(1-0,5)]}\right\}^{2}+3 \\
n=\frac{10,523536}{0,3017}+3 \\
n=34,8807955+3 \\
n=37,8807955 \\
n \approx 38
\end{gathered}
$$

Keterangan:

n : besar sampel

$\mathrm{Za}$ : simpangan baku kesalahan tipe 1

$\mathrm{Z}_{\mathrm{B}} \quad$ : simpangan baku kesalahan tipe 2

$\mathrm{r} \quad$ : koefisien korelasi

b. Perhitungan koreksi besar sampel untuk antisipasi drop out

$$
\begin{gathered}
n^{\prime}=\frac{n}{(1-f)} \\
n^{\prime}=\frac{38}{(1-0,1)} \\
n^{\prime} \approx 42
\end{gathered}
$$

Keterangan:

$$
\begin{array}{ll}
\text { n' } & \text { : besar sampel dengan drop out } \\
\mathrm{n} & \text { : besar sampel yang dihitung } \\
\mathrm{f} & : \text { perkiraan proporsi drop out }(10 \%)
\end{array}
$$

Besar sampel minimal yaitu 42 dan peneliti menentukan jumlah sampel penelitian ini 42 responden terbagi menjadi 6 perlakuan dengan tiap perlakuan 7 responden. Teknik pengambilan sampel menggunakan metode simpel random sampling. Kriteria inklusi sampel: (1) Mahasiswa Laki-laki FK UNEJ berusia 1824 tahun dengan Indeks Massa Tubuh (IMT) normal $18,5-25 \mathrm{~kg} / \mathrm{m}^{2}$; (2) Mengetahui dan dapat mengukur Heart Rate (HR) dengan palpasi denyut nadi arteri radialis;. (3) Beragama islam serta mampu melaksanakan ibadah salat dan menghafal Surat Ad-Dhuha dan Al-Ikhlas yang akan dibaca ketika salat pada rakaat ganjil/genap; (4) Bersedia melakukan pertemuan secara vitual (zoom,
WA, dan sebagainya) saat pengambilan data; (5) Bukan perokok dan tidak mengonsumsi kafein minimal 2 jam sebelum pengambilan data; (6) Bukan atlet atau olahragawan, terutama yang mengikuti perlombaan atau pertandingan seperti kekuatan, ketangkasam dan kecepatan; (7) Nilai heart rate sebelum penelitian normal 60-100 denyut permenit. Kriteria eksklusi sampel kelompok kasus: (1) Keadaan sakit seperti gangguan fungsi jantung, hipertensi, trauma, maupun kondisi lainnya atau dalam perawatan selama penelitian berlangsung; (2) Memiliki kelainan kongenital pada otot dan atau tulang. Variabel bebas dalam penelitian ini yaitu rakaat salat Dhuha $(2,4,6,8,10$, dan 12). Variabel terikat pada penelitian ini yaitu peningkatan heart rate.

Peneliti menggunakan data primer, yaitu karakteristik responden berupa data diri menggunakan google form (nama, usia, jenis kelamin, berat badan, tinggi badan, nomor handphone atau Whatsapp, agama islam, dapat melaksanakan salat sunah dhuha, menghafal Surat Ad-Dhuha dan Al-Ikhlas, mahasiswa FK UNEJ angkatan 2017, 2018, atau 2019, pernah melakukan pengukuran denyut nadi radialis, bukan perokok, tidak mengonsumsi kafein sebelum pengambilan data, nilai heart rate normal 60-100 denyut permenit, bukan atlet, tidak memiliki kelainan kongenital pada otot dan atau tulang, dan tidak dalam keadaan sakit seperti gangguan fungsi jantung, hipertensi, trauma, maupun kondisi lainnya atau dalam perawatan pada kondisi saat ini) dan data HR pretest dan posttest yang didapatkan dari observasi menggunakan media teleconference (zoom). Data yang diperoleh akan dianalisis dengan tahapan cleaning, coding, entering dan analisis data menggunakan program SPSS. Data dianalisis secara univariat dengan deskriptif (rata-rata HR pretest, HR posttest, Selisih HR preposttest, HRmax, dan intensitas aktivitas fisik tiap intensitas salat) dan bivariat dengan uji pearson serta uji one way anova.

\section{HASIL PENELITIAN}


Responden penelitian berjumlah 42 orang dengan jenis kelamin keseluruhan lakilaki, rentang usia 19-23 tahun dengan ratarata usia 20,62 $\pm 1,2$. Responden penelitian ini berasal dari mahasiswa Fakultas Kedokteran Universitas Jember dengan responden terbanyak dari mahasiswa angkatan 2019 sebesar $35,7 \%$. Nilai indeks massa tubuh (IMT) responden dengan nilai terkecil 18,73 $\mathrm{kg} / \mathrm{m}^{2}$ dan terbesar $24,61 \mathrm{~kg} / \mathrm{m}^{2}$, serta ratarata IMT keseluruhan 21,92 $\pm 1,82$. Karakteristik responden penelitian ini dapat dilihat pada Tabel 1 .

Hasil analisis sosiodemografik responden meliputi nilai HR pre-posttest, selisih HR pre-posttest, HRmax, dan intensitas aktivitas fisik berdasarkan HRmax yang diperoleh dalam salat. Nilai rerata HR posttest terendah pada kategori 2 rakaat yaitu 80,57 kali permenit sedangkan nilai tertinggi pada kategori 12 rakaat yaitu 91,43 kali permenit. Pada rerata selisih HR pre-posttest, nilai terendah pada rakaat 2 yaitu 6,29 sedangkan nilai tertinggi pada rakaat 12 yaitu 17,71. Rerata HR responden pretest, posttest, dan selisih pretest-posttest serta durasi salat setiap kategori rakaatnya dapat dilihat pada Tabel 2. Rerata HRmax keseluruhan responden sebesar 199,38 $\pm 1,21$. Pada intensitas aktivitas fisik didapatkan nilai rereta terendah pada kategori 2 rakaat yaitu $42 \%$ serta rerata tertinggi pada kategori 12 rakaat yaitu $46 \%$. Kategori intensitas aktivitas fisik terbanyak pada kategori light $(40<55 \%)$ sejumlah 35 responden dari keseluruhan. Data HRmax dan intensitas aktivitas fisik dapat dilihat pada Tabel 2.

Pada penelitian ini, uji normalitas data menggunakan Shapiro-Wilk dikarenakan jumlah sampel $<50 .{ }^{4}$ Hasilnya menyatakan data tidak terdistribusi normal $(\mathrm{Sig}<0,05)$, sehingga dilakukan transformasi data. Hasil data yang telah ditransformasi dilakukan uji normalitas kembali, didapatkan data terdistribusi normal $(\mathrm{Sig}>0,05)$. Kemudian data tersebut dilakukan uji linier, didapatkan hasil data linier $(\mathrm{Sig}>0,05)$. Pada uji homogenitas varian didapatkan data homogen $($ Sig $>0,05)$.
Analisis bivariat uji one way anova didapatkan signifikansi=0,001. Hal tersebut menunjukkan adanya perbedaan signifikan pada rerata kategori. Sehingga rerata peningkatan $\mathrm{HR}$ disetiap intensitas salat memiliki perbedaan. Hasil uji one way anova dapat dilihat pada Tabel 3.

Hasil analisis bivariat menggunakan uji pearson didapatkan nilai signifikansi $=0,00$ serta nilai $\mathrm{r}$ atau koefisien korelasi=0,637. Hal tersebut menunjukkan terdapat hubungan yang kuat $(0,60<r<0,79)$ antara variabel dependen dan independen. Sehingga intensitas salat sejalan dengan peningkatan heart rate (HR). Hasil uji pearson intensitas salat terhadap peningkatan heart rate (HR) dapat dilihat pada Tabel 3. 

Tabel 1. Hasil Analisis Sosiodemografik Responden

\begin{tabular}{lccccc}
\hline Karakteristik & Min & Max & Rerata \pm SD & n (orang) & \% \\
\hline Usia & 19 & 23 & $20,62 \pm 1,2$ & 42 & \\
Jenis Kelamin & & & & 42 & \\
$\quad$-Laki-laki & & & & 0 & \\
$\quad$-Perempuan & & & & 14 & 33,3 \\
Mahasiswa Angkatan & & & 13 & 31 \\
$\quad-2017$ & & & & 15 & 35,7 \\
$\quad-2018$ & & & & 42 & \\
$\quad-2019$ & 48 & 183 & $62,22 \pm 7,5$ & 42 & \\
Berat Badan & 155 & $168,27 \pm 5,3$ & 42 & \\
Tinggi Badan & 18,73 & 24,61 & $21,92 \pm 1,82$ & & \\
Indeks Massa Tubuh & & & & & \\
(IMT) & & & & \\
\hline
\end{tabular}

Tabel 2. HR Pre-Posttest dan Selisih HR Pre-Posttest

\begin{tabular}{|c|c|c|c|c|c|c|c|c|c|c|}
\hline \multirow[t]{2}{*}{ Karakteristik } & \multirow{2}{*}{$\begin{array}{c}\text { Rerata } \\
\text { Durasi Salat } \\
\text { (menit) }\end{array}$} & \multicolumn{2}{|c|}{ Rerata HR } & \multirow{2}{*}{$\begin{array}{c}\text { Rerata } \\
\text { Selisih HR } \\
\text { Pre-Post }\end{array}$} & \multirow{2}{*}{$\begin{array}{c}\text { Rerata } \\
\text { Intensitas } \\
\text { Aktivitas } \\
\text { Fisik }(\%) \\
\end{array}$} & \multicolumn{5}{|c|}{ Kategori Intensitas Aktivitas Fisik } \\
\hline & & Pre & Post & & & $\begin{array}{c}\text { Sedentary } \\
(<40 \%)\end{array}$ & $\begin{array}{c}\text { Light } \\
(40<55 \%)\end{array}$ & $\begin{array}{l}\text { Moderate } \\
(55<70 \%)\end{array}$ & $\begin{array}{l}\text { Vigorous } \\
(70<90 \%)\end{array}$ & $\begin{array}{c}\text { High } \\
(\geq 90 \%)\end{array}$ \\
\hline \multicolumn{11}{|l|}{ Kelompok } \\
\hline \multicolumn{11}{|l|}{ Perlakuan } \\
\hline$-P 1$ & 2,62 & 74 & 80,57 & 6,29 & 40 & 2 & 5 & - & - & - \\
\hline$-\mathrm{P} 2$ & 4,87 & 78 & 85,14 & 7,43 & 43 & - & 7 & - & - & - \\
\hline - P3 & 9,88 & 74 & 85,14 & 11,43 & 43 & 3 & 4 & - & - & - \\
\hline - P4 & 12,11 & 73 & 89,14 & 16 & 45 & - & 7 & - & - & - \\
\hline - P5 & 10,1 & 74 & 90,29 & 16,57 & 45 & 1 & 5 & 1 & - & - \\
\hline - P6 & 13,35 & 74 & 91,43 & 17,71 & 46 & - & 7 & - & - & - \\
\hline
\end{tabular}

* P1, P2, P3, P4, P5, P6 : salat dhuha 2, 4, 6, 8, 10, 12 rakaat

Tabel 3. Hasil Uji Analisis Bivariat

\begin{tabular}{lcc}
\multicolumn{3}{c}{ Tabel 3. Hasil Uji Analisis Bivariat } \\
\hline Variabel & Nilai p Anova & $\begin{array}{c}\text { Nilai Korelasi } \\
\text { Pearson }\end{array}$ \\
\hline Rakaat salat dhuha-peningkatan HR & 0,001 & $0,637(0,000)$ \\
\hline
\end{tabular}




\section{PEMBAHASAN}

Hasil penelitian menunjukkan terjadi peningkatan HR yang bertahap sesuai dengan penambahan jumlah rakaat salat dhuha.

Salat sebagai kegiatan spiritual dan aktivitas fisik dilakukan dengan gerakan dan bacaan. Gerakan salat terdiri dari takbiratul ihram, berdiri, rukuk, sujud, duduk diantara dua sujud, dan duduk takhiyat. Gerakan salat melibatkan hampir seluruh otot dan persendian tubuh seperti bagian bahu, pergelangan tangan, siku, jari-jari tangan, tulang belakang, panggul, kaki, pergelangan kaki, jari kaki, dan lainnya. Salat mirip dengan latihan ringan yang membuat terjadinya kontraksi otot secara isometrik dan isotonik. ${ }^{15}$ Respon tubuh terhadap kontraksi otot menyebabkan penekanan pembuluh darah yang melibatkan mekanisme lokal dan sistemik. Untuk mempertahankan aliran darah, tubuh akan merespon dengan mekanisme lokal seperti penurunan $\mathrm{PO}_{2}$ jaringan, peningkatan $\mathrm{PCO}_{2}$ jaringan, dan akumulasi $\mathrm{K}^{+}$serta metabolit vasodilator lainnya. Respon kardiovaskular sistemik dipengaruhi oleh jenis kontraksi otot isometrik dan isotonik yang dapat mengakibatkan peningkatan denyut jantung. ${ }^{16}$ Denyut jantung dihasilkan oleh potensial aksi didalam simpul sinus yang menjalar dari dinding lateral atrium hingga ventrikel. Hal tersebut membuat ventrikel memompa darah ke sistem pembuluh darah. ${ }^{7}$

Penelitian Tanzila dan Bustan bertujuan untuk mengetahui pengaruh latihan interval intensitas tinggi terhadap denyut nadi mahasiswa Fakultas Kedokteran Universitas Muhammadiyah Palembang. Penelitian tersebut dilakukan pengukuran nadi awal dan sesudah latihan intensitas tinggi dalam waktu tertentu. Hasil penelitian menunjukkan terjadi peningkatan denyut nadi setelah latihan interval intensitas tinggi, dengan nilai rata-rata sebelum latihan $85,33 \pm 10,993$ dan setelah latihan $152 \pm 8,975 .^{17}$

Penelitian Elly dalam Panggalih dkk., bertujuan untuk mengetahui aktivitas turun tangga terhadap peningkatan frekuensi denyut nadi mahasiswa. Analisis penelitian menggunakan uji t-berpasangan menunjukkan $p=0,00$ yang berarti terdapat perbedaan bermakna antara denyut nadi awal dan denyut nadi setelah naik turun tangga. Peningkatan denyut nadi setelah aktivitas naik turun tangga dengan nilai rata-rata awal 72,09 kali permenit dan setelah naik turun tangga 74,49 kali permenit. ${ }^{18}$

Gerakan salat disebut Namaz menurut Haque dan Ghosh merupakan bentuk latihan fisik intensitas ringan (mild exercise). Namaz merupakan latihan yang baik terhadap jantung. Gerakan salat melibatkan seluruh bagian tubuh yang dilakukan 5 kali sehari, sehingga mampu menjaga tubuh sepanjang waktu tanpa menyebabkan strain atau kelelahan. $^{8}$ Menurut Noorbhai, salat termasuk aktivitas fisik low intensity yang menyebabkan relaksasi, menurunkan stres, memperlancar aliran darah, serta memperkuat otot dan persendian. ${ }^{11}$

Penelitian Panggalih dkk. bertujuan untuk mengetahui perbedaan tekanan darah dan denyut jantung pada berbagai intensitas latihan atlet balap sepeda. Hasil penelitian menggunakan analisis one way anova menunjukkan terdapat perbedaan yang signifikan perubahan denyut jantung disetiap intensitas latihan. Hasil pengukuran denyut nadi pada intensitas ringan didapatkan perubahan atau selisih pretest-posstest $12,18 \pm 5,63$ kali permenit, intensitas sedang $26,72 \pm 14,71$ kali permenit, serta intensitas tinggi $10,54 \pm 11,95$ kali permenit. Sehingga perubahan HR pada intensitas sedang lebih tinggi daripada intensitas ringan, sedangkan intensitas tinggi lebih rendah daripada intensitas sedang. ${ }^{18}$

Intensitas latihan atau aktivitas fisik menurut Janssen dalam Sandi dengan HR memiliki hubungan linear. Apabila intensitas ditambah maka terjadi peningkatan HR, begitu pula sebaliknya. Namun pada kondisi tertentu, HR memiliki titik ambang batas, sehingga tidak terjadi peningkatan linear atau menjadi melengkung yang berarti saat aktivitas fisik tersebut mencapai titik maksimal maka perubahan denyut jantung tidak mengikuti peningkatan intensitasnya. ${ }^{19}$ 
Intensitas latihan atau aktivitas fisik yang sesuai dapat bermanfaat terhadap kebugaran jasmani. Unsur terpenting dalam kebugaran jasmani yaitu daya tahan kardiorespirasi sebagai fungsi kesanggupan jantung dan paru saat istirahat atau beraktivitas untuk mengambil oksigen dan menyebarkannya keseluruh tubuh. ${ }^{18}$ Adaptasi tubuh terhadap latihan kebugaran jasmani memengaruhi efisiensi kerja jantung, peningkatan isi sekuncup, dan kontraksi jantung lebih kuat. Sehingga frekuensi denyut jantung saat istirahat mengalami penurunan atau dibawah orang normal. ${ }^{20}$

Manfaat latihan fisik intensitas ringan dibuktikan dalam beberapa penelitian seperti Brown dkk. dengan menerapkan latihan intensitas rendah selama 3 bulan pada peserta usia dewasa yang lebih tua menunjukkan hasil perbaikan di semua domain fisik serta meningkatkan rasa kenikmatan dan peningkatan kinerja fisik. ${ }^{21}$ Penelitian Motl dkk. mengenai intervensi latihan fisik terdahap depresi pada usia dewasa tua menunjukkan penurunan depresi yang signifikan setelah intervensi 6 bulan serta pengecekan lanjutan dalam 12 dan 60 bulan. $^{22}$

Salat sebagai aktivitas fisik intensitas ringan mampu meningkatkan koordinasi, sirkulasi, keseimbangan, kapasitas aerobik, serta menurunkan resiko stroke hemoragik. ${ }^{8}$ Salat yang dilakukan 5 kali sehari dengan rutin memiliki efek positif terhadap kualitas hidup dan tingkat kesegaran jasmani seperti kekuatan, ketahanan, fleksibiliti, keseimbangan, dan koordinasi pada lansia. ${ }^{12}$

Penelitian ini memiliki beberapa kelebihan berkaitan pengambilan data. Peneliti memakai media elektronik berbasis teleconference atau video call dalam melakukan observasi langsung dengan responden saat pengambilan data. Sehingga mampu dilakukan di era pandemi Covid-19 tanpa menimbulkan resiko penyebaran penyakit. Penggunakan simple random sampling dengan memilih responden berdasarkan kriteria inklusi dan ekslusi diharapkan mampu menghomogenkan responden penelitian serta didapatkan hasil penelitian yang lebih valid.

Terdapat keterbatasan yang disadari peneliti dalam penelitian ini yaitu faktor lain yang tidak dikontrol peneliti seperti suhu lingkungan dan kondisi psikologis. Oleh karena itu, diharapkan pada penilitian selanjutnya dapat mempertimbangkan semua faktor yang memengaruhi HR. Serta dapat mengembangkan ide penelitian mengenai salat terhadap kesehatan seperti kebugaran jasmani, sistem kardiovaskular atau sistem lainnya dibidang biomolekuler, serta behubungan penyakit degeneratif atau lainnya.

\section{KESIMPULAN}

Berdasarkan hasil analisis dan pembahasan maka kesimpulan dari penelitian ini adalah sebagai berikut. Terdapat hubungan positif antara penambahan rakaat salat dhuha terhadap peningkatan heart rate (HR). Perubahan HR pretest dan posttest pada intensitas salat yaitu 6,29 pada 2 rakaat, 7,43 pada 4 rakaat, 11,43 pada 6 rakaat, 16 pada 8 rakaat, 16,57 pada 10 rakaat, dan 17,71 pada 12 rakaat. Nilai intensitas salat berdasarkan HRmax pada intensitas salat yaitu $40 \%$ pada 2 rakaat, $43 \%$ pada 4 rakaat, $43 \%$ pada 6 rakaat, $45 \%$ pada 8 rakaat, $45 \%$ pada 10 rakaat, dan $46 \%$ pada 12 rakaat. Berdasarkan nilai rerata tersebut, salat dengan kategori 2, 4, 6, 7, 8, 10, dan 12 rakaat termasuk aktivitas fisik light or low intensity.

\section{UCAPAN TERIMA KASIH}

Peneliti mengucapkan terimakasih kepada Fakultas Kedokteran Universitas Jember dan responden penelitian atas partisipasi yang diberikan dalam penulisan artikel penelitian ini.

\section{DAFTAR PUSTAKA}

1. WHO. Basic Documents Fourty-ninth Edition. Geneva: World Health Organization; 2020. 
2. Michael S, Yunus E. Hubungan Aktivitas Fisik Dengan Tekanan Darah Pada Orang Dewasa. CHMK Nursing Scientific Journal. 2020;4.

3. RI DPKdPMK. Promosi Kesehatan https://promkes.kemkes.go.id/promosikesehatan2016 [

4. WHO. Physical Activity and Sedentary Beharvior. Geneva: World Health Organization; 2020.

5. Tse AC, Wong TW, Lee PH. Effect of Low-intensity Exercise on Physical and Cognitive Health in Older Adults: a Systematic Review. Sports Med Open. 2015;1(1):37.

6. Vega RB, Konhilas JP, Kelly DP, Leinwand LA. Molecular Mechanisms Underlying Cardiac Adaptation to Exercise. Cell Metab. 2017;25(5):101226.

7. Guyton AC, Hall JE. Buku Ajar Fisiologi Kedokteran. Amerika Serikat: Saunders Elsevier; 2011.

8. Haque A, Ghosh SS. Namaz is a Very Good Exercise for Whole Some Development. Global Research Analysis. 2013;2:220-1.

9. Rifa'i M. Risalah Tuntunan Shalat Lengkap. Semarang: PT. Karya Toha Putra; 2020.

10. Ibrahim F, Ahmad WAW. Study of Heart Rate Changes in Different Salat's Positions. IFMBE Proceedings. 2008;21:687-90.

11. Noorbhai MH. The Utilization and Benefits of Salaah (Muslim Prayer) as a Means of Functional Rehabilitation and Low-Intensity Physical Activity. The Experiment. 2013;7(3):401-3.

12. Yusek S. The Effects of Performing Prayer on the Physical Fitness Levels of Men Over 60 Yeats Old. Journal of Education and Training Studies. 2017;5:56-63.

13. Sastroasmoro S, Ismael S. Dasar-dasar Metodologi Penelitian Klinis. Jakarta: CV Sagung Seto; 2014.

14. Syahdrajat T. Panduan Penelitian untuk Skripsi Kedokteran dan Kesehatan. Jakarta: Fizky Offset; 2019.
15. Nazish N, Kalra N. Muslim Prayer - A New Form of Physical Activity: A Narrative Review. International Journal of Health Science and Research. 2018;8(7):337-4.

16. Barrett KE, Barman SM, Boitano S, Brooks HL. Ganong's Review of Medical Physiology 24th Edition. United States: McGraw-Hill Companies; 2012.

17. Tanzila RA, Bustan MF. Pengaruh Latihan Interval Intensitas Tinggi terhadap Denyut Nadi Mahasiswa Kedokteran. Global Medical and Health Communication. 2017;5(1):47-50.

18. Panggalih MHST, Hardiyanti M, Sani FI. Perbedaan Tekanan Darah dan Denyut Jantung pada Atlet Balap Sepeda. Jurnal Keolahragaan. 2015;3(2):218-27.

19. Sandi IN. Pengaruh Latihan Fisik terhadap Frekuensi Denyut Nadi. Sport and Fitness Journal. 2016;4(2):1-6.

20. Rifa'i R, Purwanti, Firranda F. Pengaruh Frekuensi Latihan Kebugaran Jasmani dengan Denyut Nadi di Desa Sentul Tembelang Jombang. Nursing Sciences Journal. 2020;4(1):1-7.

21. Brown M, Sinacore DR, Ehsani AA, Binder EF, Holloszy JO, Kohrt WM. Low-intensity exercise as a modifier of physical frailty in older adults. Arch Phys Med Rehabil. 2000;81(7):960-5.

22. Motl RW, Konopack JF, McAuley E, Elavsky S, Jerome GJ, Marquez DX. Depressive symptoms among older adults: long-term reduction after a physical activity intervention. $J$ Behav Med. 2005;28(4):385-94. 